\title{
Assessment of Water Quality in Kalundu Stream and Kalundu dam in Kitui County, Kenya
}

\author{
Julius Kioko Nzeve* Andrean Mutuku Matata \\ Department of Environmental Sciences, Machakos University, \\ P.O. Box 136 - 90100, Machakos, Kenya
}

\begin{abstract}
This study aimed to assess levels of selected physico-chemical and bacteriological loads of Kalundu stream and Kalundu dam. Sampling was conducted from February to April 2019 in three selected sampling sites. Surface water samples were collected and analyzed for fifteen physico-chemical parameters. Water temperature, $\mathrm{pH}$, turbidity and electrical conductivity were measured on site. Biological oxygen demand (BOD), Chemical Oxygen Demand (COD), total hardness and alkalinity, selected major anions and cations were analyzed at a Water Resources Authority laboratory using standard procedures. Data analysis was carried out using one-way analysis of variance and significant differences accepted at $\mathrm{p} \leq 0.05$. Results showed that $\mathrm{pH}$, fluoride, sulphates, total hardness and alkalinity were within WHO set standards for drinking water. However, turbidity, EC, Fe, Ca, Mg, Nitrites and Chlorides were above the WHO recommended levels for drinking water. Both total coliforms and $E$. coli were exceedingly high and ranged from $385 \pm 188.9$ to $337,133 \pm 124,970 \mathrm{MPN} / 100 \mathrm{ml}$ and $70.70 \pm 46.50$ to $3941183 \pm 2771080 \mathrm{MPN} / 100 \mathrm{ml}$ respectively. The findings revealed that water quality of Kalundu stream and Kalundu dam is highly polluted with pathogenic microorganisms and a potential risk to human health. Therefore, measures to curb microbial pollution should be taken by the relevant municipality authorities of Kitui County government.
\end{abstract}

Keywords: Assessment, Water quality, Bacteriology, Kalundu dam, Kitui County

DOI: $10.7176 / \mathrm{JEES} / 11-1-05$

Publication date: January $31^{\text {st }} 2021$

\section{Introduction}

Water is a finite natural resource which forms the main source of life on earth. It is characterized by its vast distribution around the globe covering three quarters of the earth's surface. Access to clean water is essential for health, economic and social well-being of any human population (Chakravarty et al., 2017). However, in many developing countries, water quality is the main concern for it has been compromised due to wide range of natural and human influences (Bhaja and Kundu, 2012). Water quality is the chemical, physical and organic characteristics of water and its appropriateness for assigned use (Daniel et al., 2008). Access to a safe drinking water is a basic human right and an effective policy for health protection given that clean, safe and enough freshwater is crucial to the survival of all human beings (Masese et al., 2017). There is high demand for water in developing countries due to population increase, urbanization, industrialization and agriculture (Chatanga et al., 2019). This has resulted to water pollution and especially in major towns and cities. According to Genevieve and Neary (2008), the pollution in urban areas is result from human activities and inadequate wastewater treatment facilities. Water pollution due to use of agrochemicals, heavy metals, industrial effluents and poor urban planning have had adverse effects on environment and human health. This has led to illness of millions of people annually across the globe (Kolpin et al., 2002; WHO, 2004).

Kalundu dam is located in lower Tana catchment area in Kitui town, which is a fast-growing town in the south eastern part of Kenya. The town over the past recent years has been characterized by high population growth and water scarcity. The dam has long been faced with upstream pollution over the years mainly from domestic and municipal sources such as garbage, slaughter houses and solid waste dumpsites which are located upstream. This has led to solid depositions mainly plastics on the banks of the dam. This study therefore, sought to assess the physico-chemical and bacteriological loads of water in Kalundu stream and Kalundu dam, Kitui County, Kenya.

\section{Materials and Methods}

\subsection{Study area}

The study was carried out in Kalundu dam which is located south west of Kitui town along Kalundu stream. The dam supplies water to over 80,000 people around Majengo, Kaveta and Ithookwe sub-locations thus making the dam very useful to the local people. The dam lies at latitude -1.366667 and longitude 37.983333 .

\subsection{Water Sampling and Analysis}

Sampling was done once per month from February to April 2019 in three selected sampling stations. Sampling site one (S1) was the area just after the solid waste dumpsite, while site two (S2) was at Kalundu stream which passes through residential areas and Kitui milling company and site three (S3) was at Kalundu dam. Water samples 
were collected at 10 to $15 \mathrm{~cm}$ below the surface water using sterilized $500 \mathrm{ml}$ glass bottles. The samples were collected in triplicates from each sampling sites. After each sample was collected, the glass bottles were immediately closed tightly, labelled and covered with aluminum foil and placed in an icebox. The samples were then transported to the Water Resources Authority (WRA) Central laboratory in Nairobi and kept at $4^{0} \mathrm{C}$ awaiting analysis. Microbiological analyses were done within 24 hours of sample collection. In situ field parameters such as Temperature, $\mathrm{pH}$, Electrical conductivity (EC), and turbidity were measured on site using a multiparameter probe YSI Meter (model 1945). Ex-situ parameters such as Iron (Fe), Magnesium (Mg) and Calcium (Ca) were determined by volumetric titration method, while Chlorides $\left(\mathrm{Cl}^{-}\right)$was determined by titration method using silver nitrate and potassium chromate. Fluoride $\left(\mathrm{F}^{-}\right)$was determined by Selective Electrode Method and total hardness was determined by volumetric titration using ethylene-diamine-tetra-acetic acid (EDTA), alkalinity by titration method (APHA, 1999). Sulphates were determined by turbidimetric method while Nitrite and Fluoride were determined by photometric method. Biochemical oxygen demand (BOD) was measured by the 5-day incubation method at $20^{\circ} \mathrm{C}$. Bacteriological tests were carried out using the 'most probable number (MPN)' estimations standards procedures (APHA, 1999).

\subsection{Data analysis}

Water quality data collected were analyzed using Statistical Package for Social Sciences (SPSS IBM version 21). One-way Analysis of variance (ANOVA) was used to test significance differences $(p \leq 0.05)$ among the different sampling sites. Post hoc Turkey test analysis were done to separate means where significant differences occurred among the sampling sites. The water quality parameters were also compared with WHO water quality standards for drinking water (WHO, 2017).

\subsection{Results and Discussions}

\subsection{Water temperature, pH, Turbidity and Electrical Conductivity}

The means \pm standard deviations and range of the physicochemical parameters are presented in Table 1 . The mean water temperature ranged from $25.08 \pm 0.57$ to $25.39 \pm 1.02^{\circ} \mathrm{C}$ which was slightly above the WHO set guidelines for drinking water. Temperature influences the general quality of water and thus affects the distribution, health and survival of aquatic organisms (Osman and Kloas, 2010). $\mathrm{pH}$ mean values among the sampling sites ranged from $7.65 \pm 0.05$ to $7.68 \pm 0.07$. This was within the WHO set limit for drinking water and there were no significant differences among the sampling sites $(\mathrm{p}=0.994) \mathrm{pH}$ is very important because many biological activities in an aquatic system occur within a specific $\mathrm{pH}$ ranges and major variations could be fatal to aquatic organisms. Turbidity exhibited significant differences among the sampling sites $(\mathrm{p}=0.001)$ and was way above the WHO recommended set limits for drinking water. Site 2 which was next to Kitui solid waste dumpsite showed significant differences $(p=0.001)$ from site 1 and site 3 . The mean turbidity values ranged from $27.75 \pm 11.65$ to $251.41 \pm 173.67$ NTUs. Site 2 had very high turbidity levels compared to the rest. This could be attributed to anthropogenic activities and municipal wastes from the solid waste dumpsite. Electrical conductivity showed significant differences $(p=0.00)$ among the three sampling sites with site 1 and site 2 exhibiting higher levels of EC beyond the WHO recommended limits for drinking water. EC is an indicator of dissolved ions in water and the ions can alter the taste of water and contribute to its hardness (Nienie et al., 2017).

\subsection{Total Hardness and Alkalinity}

The mean values for total hardness and total alkalinity were below WHO set guidelines. There were significant differences among the sampling sites both for total hardness and total alkalinity $(\mathrm{p} \leq 0.05)$. The highest total hardness and alkalinity of $451.67 \pm 29.94 \mathrm{mg} / \mathrm{L}$ and $368.33 \pm 23.85 \mathrm{mg} / \mathrm{L}$ respectively were recorded at S2 (Table 1). 
Table 1: Mean \pm standard deviations, range (minimum - maximum) physico-chemical parameters per sampling site

\begin{tabular}{|c|c|c|c|c|c|}
\hline \multirow[t]{2}{*}{ Parameter } & Site one (S1) & Site two (S2) & Site three(S3) & \multirow{2}{*}{$\begin{array}{l}\text { WHO } \\
\text { standard }\end{array}$} & \multirow{2}{*}{$\begin{array}{l}\mathrm{P} \\
\text { Value }\end{array}$} \\
\hline & Mean \pm StDev & Mean \pm StDev & Mean \pm StDev & & \\
\hline Temperature $\left(0^{0} \mathrm{C}\right)$ & $\begin{array}{l}25.08 \pm 0.57 \\
24.40-25.60\end{array}$ & $\begin{array}{l}25.13 \pm 1.08 \\
24-26.60\end{array}$ & $\begin{array}{l}25.39 \pm 1.02 \\
24-26.70\end{array}$ & 25 & 0.793 \\
\hline $\mathrm{pH}$ & $\begin{array}{l}7.68 \pm 0.07 \\
7.63-7.81\end{array}$ & $\begin{array}{l}7.65 \pm 0.50 \\
7.10-8.20\end{array}$ & $\begin{array}{l}7.66 \pm 0.54 \\
6.40-8.12\end{array}$ & $6.5-8.5$ & 0.994 \\
\hline Turbidity (NTUs) & $\begin{array}{l}45.78 \pm 20.61 \\
26.38-72.00\end{array}$ & $\begin{array}{l}251.41 \pm 173.67 \\
55-444.00\end{array}$ & $\begin{array}{l}27.75 \pm 11.65 \\
20.24-58.00\end{array}$ & 5 & 0.001 \\
\hline $\mathrm{EC}(\mu \mathrm{S} / \mathrm{cm})$ & $\begin{array}{l}1819.17 \pm 137.91 \\
1658-1959\end{array}$ & $\begin{array}{l}1736.67 \pm 58.01 \\
1650-1795\end{array}$ & $\begin{array}{l}438.22 \pm 9.24 \\
428-454\end{array}$ & 1500 & 0.000 \\
\hline Nitrites $(\mathrm{mg} / \mathrm{L})$ & $\begin{array}{l}50.00 \pm 32.24 \\
20.0-90.00\end{array}$ & $\begin{array}{l}211.67 \pm 173.71 \\
30.0-430.0\end{array}$ & $\begin{array}{l}54.56 \pm 30.33 \\
20.00-119.0\end{array}$ & 0.1 & 0.010 \\
\hline $\mathrm{BOD}(\mathrm{mg} / \mathrm{L})$ & $\begin{array}{l}0.015 \pm 0.01 \\
0.00-0.03\end{array}$ & $\begin{array}{l}0.041 \pm 0.05 \\
0.00-0.12 \\
\end{array}$ & $\begin{array}{l}0.06 \pm 0.04 \\
0.01-0.13\end{array}$ & - & 0.123 \\
\hline $\mathrm{COD}(\mathrm{mg} / \mathrm{L})$ & $\begin{array}{l}753.71 \pm 435.05 \\
277.44-1491.24\end{array}$ & $\begin{array}{l}3752.38 \pm 3495.52 \\
457.78-9537.0\end{array}$ & $\begin{array}{l}717.11 \pm 658.32 \\
104.04-1872.72 \\
\end{array}$ & - & 0.015 \\
\hline Sulphates (mg/L) & $\begin{array}{l}70.72 \pm 60.15 \\
25.67-170.96\end{array}$ & $\begin{array}{l}260.06 \pm 206.93 \\
30-494.29\end{array}$ & $\begin{array}{l}11.64 \pm 8.34 \\
5.18-31.99\end{array}$ & 450 & 0.002 \\
\hline Fluorides (mg/L) & $\begin{array}{l}0.92 \pm 0.06 \\
0.85-0.99\end{array}$ & $\begin{array}{l}1.20 \pm 0.17 \\
0.93-1.40\end{array}$ & $\begin{array}{l}0.58 \pm 0.14 \\
0.47-0.93\end{array}$ & 1.5 & 0.000 \\
\hline Chlorides (mg/L) & $\begin{array}{l}360.83 \pm 17.15 \\
340-380\end{array}$ & $\begin{array}{l}245.83 \pm 19.34 \\
225-270.0\end{array}$ & $\begin{array}{l}98.22 \pm 81.35 \\
42.00-210.0\end{array}$ & 250 & 0.000 \\
\hline $\begin{array}{l}\text { Total alkalinity } \\
(\mathrm{mg} / \mathrm{L})\end{array}$ & $\begin{array}{l}368.33 \pm 23.85 \\
344-398\end{array}$ & $\begin{array}{l}254.33 \pm 181.67 \\
120-488.0\end{array}$ & $\begin{array}{l}142.44 \pm 13.03 \\
128-170.0\end{array}$ & 500 & 0.001 \\
\hline $\begin{array}{ll}\text { Total } & \text { Hardness } \\
(\mathrm{mg} / \mathrm{L}) & \\
\end{array}$ & $\begin{array}{l}451.67 \pm 29.94 \\
420-490\end{array}$ & $\begin{array}{l}363.33 \pm 52.41 \\
300-420.0 \\
\end{array}$ & $\begin{array}{l}128.44 \pm 5.27 \\
122-136.0\end{array}$ & 500 & 0.000 \\
\hline $\mathrm{Fe}(\mathrm{mg} / \mathrm{L})$ & $\begin{array}{l}0.38 \pm 0.36 \\
0.14-1.10\end{array}$ & $\begin{array}{l}0.96 \pm 0.72 \\
0.31-2.36\end{array}$ & $\begin{array}{l}0.56 \pm 0.44 \\
0.09-1.47\end{array}$ & 0.3 & 0.167 \\
\hline $\mathrm{Mg}(\mathrm{mg} / \mathrm{L})$ & $\begin{array}{l}65.64 \pm 11.99 \\
51.07-80.21 \\
\end{array}$ & $\begin{array}{l}102.58 \pm 102.54 \\
29.22-239-76\end{array}$ & $\begin{array}{l}33.92 \pm 32.54 \\
10.71-79.92\end{array}$ & 100 & 0.111 \\
\hline $\mathrm{Ca}(\mathrm{mg} / \mathrm{L})$ & $\begin{array}{l}150.44 \pm 63.87 \\
70.49-209.79 \\
\end{array}$ & $\begin{array}{l}74.69 \pm 58.45 \\
29.22-149.85 \\
\end{array}$ & $\begin{array}{l}57.39 \pm 34.18 \\
11.68-87.91 \\
\end{array}$ & 100 & 0.008 \\
\hline
\end{tabular}

\subsection{Major Cations}

The mean values for iron (Fe) ranged from $0.38 \pm 0.36$ to $0.96 \pm 0.72 \mathrm{mg} / \mathrm{L}$. All the sampling sites recorded mean values that were above the set WHO guidelines for drinking water. There were no significant differences among the three sampling sites $(\mathrm{p}=0.167)$. Sampling site $\mathrm{S} 2$ recorded Magnesium mean values of $102.58 \pm 102.52 \mathrm{mg} / \mathrm{L}$ that was slightly higher than WHO set standards unlike sampling sites S1 and S3 that had lower concentrations levels. Among the three sampling sites, there were no significant differences in concentrations of magnesium cations in water. For Calcium mean concentrations, sampling site $\mathrm{S} 1$ recorded significantly higher values $(\mathrm{p}=0.008)$ compared to the rest of the sampling sites and were higher than WHO set standards.

\subsection{Major Anions}

All the sampling sites recorded Nitrites mean values that were above the WHO set guidelines for drinking water. Sampling site S2 exhibited higher values $211.67 \pm 173.71 \mathrm{mg} / \mathrm{L}$ that were significant different from those of sampling sites S1and S3. However, post hoc Tukey test showed that nitrite values recorded at sampling sites S1 and S3 did not differ significantly ( $\mathrm{p}=0.995)$. The mean values for sulphates showed significant differences among the sampling sites $(\mathrm{p}=0.002)$, where post hoc Tukey HSD showed that all sampling sites significant differed from the other. However, all the sulphates mean values were below the WHO set guidelines for drinking water. Fluoride values ranged from 0.47 to $1.40 \mathrm{mg} / \mathrm{L}$ and the mean vales for sampling sites $\mathrm{S} 1, \mathrm{~S} 2$, S3 were $0.92 \pm 0.06,1.20 \pm 0.17$ and $0.58 \pm 0.14 \mathrm{mg} / \mathrm{L}$ respectively. Sampling site $\mathrm{S} 2$ exhibited significant differences from the $\mathrm{S} 1$ and $\mathrm{S} 3(\mathrm{p}=0.00)$. The fluoride mean values were below the WHO set guidelines. Fluoride ions in low concentrations are important for normal mineralization of bones and formation of dental enamel (Peckham and Awofeso, 2014). Fluoride ions concentrations above $1.5 \mathrm{mg} / \mathrm{L}$, when ingested directly or indirectly causes fluorosis, which is a condition of slow and progressive decay of bones and teeth (Firempong et al., 2013). The chloride values recorded at the different sampling sites ranged from 42 to $380 \mathrm{mg} / \mathrm{L}$ with mean values of $360.83 \pm 17.15 \mathrm{mg} / \mathrm{L}, 245.33 \pm 19.34 \mathrm{mg} / \mathrm{L}$ and 
$98.22 \pm 81.25 \mathrm{mg} / \mathrm{L}$ for sampling sites S1, S2, and S3 respectively. All the chloride mean values for the three sites had significant differences for each other $(\mathrm{p}=0.00)$. Mean values for Sampling site $\mathrm{S} 1$ exceeded the WHO set limits for drinking water.

\subsection{Biochemical Oxygen Demand (BOD) and Chemical Oxygen Demand (COD)}

The BOD values recorded ranged from 0.00 to $0.13 \mathrm{mg} / \mathrm{L}$ with highest mean values of $0.06 \pm 0.04 \mathrm{mg} / \mathrm{L}$ being recorded at sampling site S3. There were no significant differences in BOD concentration levels in the three sampling sites $(\mathrm{p}=0.123)$. COD values recorded ranged from 104.04 to $9537.0 \mathrm{mg} / \mathrm{L}$ with a mean value of $3752.38 \pm 3485.52 \mathrm{mg} / \mathrm{L}$ measured at sampling site $\mathrm{S} 2$ which exhibited significant difference from the other two sampling sites $(p=0.015)$. The mean COD values recorded were higher than those recorded at Mitheu stream in Machakos town (Kitulu et al., 2020) but the mean BOD levels were lower in the same urban stream.

\subsection{Bacteriological loads}

The mean values of bacteriological counts for water are presented in Table 2. The total coliform counts ranged from $385 \pm 188.9$ to $337,133 \pm 124,970 \mathrm{MPN} / 100 \mathrm{ml}$ and varied significantly among the sampling sites $(\mathrm{p}=0.00)$. There was a sharp increase of total coliforms at site 2 and this could be attributed to residential areas around the site. However, the coliform bacteria count decreased drastically at site 3 which was a site inside Kalundu dam. Coliform bacteria are a pointer to presence of pathogenic microbes that are harmful to human health and aquatic life. This means that water in Kalundu dam is highly contaminated by pathogenic microorganisms. Total coliform and E. coli are indicators of microbial contamination (Donze, 2004). These pathogenic microorganisms have their source from human and animal wastes and pose a threat to human health through ingestion of contaminated water. There was significant difference of $E$. coli mean values measured at the three sampling sites $(\mathrm{p}=0.00)$. The highest values were obtained at site 2 possibly due to presence of residential areas. The bacterial counts for both total coliforms and E. coli exceeded the WHO set limits which recommends $0 \mathrm{MPN} / 100 \mathrm{~mL}$ for drinking water. Kalundu stream and Kalundu dam are therefore contaminated with pathogenic microbes. Microbial contamination in the study area is coming from domestic wastes, untreated municipal wastes and urban runoff in the riverine system. The findings were comparably lower than those recorded by Kitulu et al, (2020) in Mitheu stream in Machakos town.

Table 2: Mean \pm standard deviations, range (minimum - maximum) bacteriological loads per sampling site

\begin{tabular}{|l|l|l|l|l|l|}
\hline \multirow{2}{*}{ Parameter } & Site one (S1) & Site two (S2) & Site three (S3) & WHO & P -Value \\
\cline { 2 - 6 } & Mean \pm StDev & Mean stDev StDerd & Mean \pm StDev & \\
\hline Total coliforms & $385.5 \pm 188.9$ & $347133 \pm 124970$ & $8443 \pm 9284$ & Nil & 0.00 \\
(MPN/100ml) & $100-620$ & $208700-527000$ & $403-20100$ & & \\
\hline E. Coli & $70.70 \pm 46.50$ & $394183 \pm 277108$ & $9337 \pm 10891$ & Nil & 0.00 \\
(MPN/100ml) & ND -110 & $308900-632800$ & $1290-27910$ & & \\
\hline
\end{tabular}

\section{Conclusion and Recommendations}

Kalundu stream and Kalundu dam is contaminated with organic and inorganic compounds both from domestic and municipal point source pollution in Kitui town. Pollutant distribution and fluctuations in Kalundu stream was found to reduce downstream up to Kalundu dam with only slight increase in BOD levels. Kitui dumpsite was however found to be a major contributor of nitrite compounds which are in toxic levels and hence immediate remediation strategies are required. Generally, both dam and the Kalundu stream have high levels of nitrites and inorganic materials and hence water is not safe for drinking. The findings indicated that water in Kalundu dam has potential risks to human health due to high levels of pathogenic microorganisms, total coliforms and E. coli. Therefore, measures to curb microbial pollutions should be taken by the relevant municipality authorities of Kitui County government. This can be achieved by having proper waste treatment and sanitation systems within the municipality.

\section{Acknowledgements}

The authors appreciate Water Resources Authority (WRA), Nairobi for availing their laboratory facility during analysis of water samples.

\section{References}

APHA (1999). Standard methods for the Examination of water and wastewater. American Public Health Association. Washington DC.

Bhaja, P \& Kundu, R (2012). Status of the seawater quality at few industrially important coasts of Gujarat (India) Off Arabian Sea. Indian J. Geo-Mar. Sci. 41 (1), 90-97.

Chakravarty, I \& Bhattacharya, A.S.K (2017). Water, sanitation and hygiene: The unfinished agenda in the World Health Organization South-East Asia Region. WHO South-East Asia J Public Health 2017; 6:22-33 DOI: 


\section{$10.4103 / 2224-3151.213787$}

Chatanga, P., Ntuli, V., Mugomeri, E., Keketsi, T \& Chikowore, N.V.T (2019) Situational analysis of physicochemical, biochemical and microbiological quality of water along Mohokare River, Lesotho. The Egyptian Journal of Aquatic Research Volume 45, Issue 1, March 2019, Pages 45-51. https://doi.org/10.1016/j.ejar.2018.12.002

Daniels, M., Scott, T., Haggard, B., Sharpley, A \& Daniel, T (2008). What is water quality? Available at: https://www.uaex.edu/publications/pdf/FSA-9528.pdf.

Donze, J.L (2004). Factors Affecting Total Coliform and Escherichia coli Bacterial Counts at 30 Lakes in Hillsborough Country, Florida. Available at: http://lakewatch.ifas.ufl.edu/pub.

Firempong, C., Nsiah, K., Awunyo-Vitor, D \& Dongsogo, J (2013). Soluble fluoride levels in drinking water-a major risk factor of dental fluorosis among children in bongo community of Ghana, Ghana Med. J. 47 (1) (2013) 16-23.

Geneviève, M.C \& Neary, J.P (2008). Water Quality for Ecosystem and Human Health. GERMS, Canada.

Kitulu, L., Nzeve, J.K., Waswa, F., Kitur, E \& Shitanda, D. (2020). Irrigation water quality analysis of Mitheu Stream in Machakos Municipality, Kenya. African Journal of Environmental Science and Technology, 14(9), 241-249. https://doi.org/10.5897/AJEST2020.2849

Kolpin, D.W., Furlong, E.T., Meyer, M.T., Thurman, E.M., Zaugg, S.D., Barber, LB \& Buxton, HT (2002). Pharmaceuticals, hormones, and other organic wastewater contaminants in U.S. streams, 1999-2000: a national reconnaissance. Environ. Sci. Technol. 36, 1202-1211. https://doi.org/10.1021/es011055j.

Masese, F.O., Salcedo-Borda, J.S., Gettel, G.M., Irvine, K \& McClain (2017). Influence of catchment land use and seasonality on dissolved organic matter composition and ecosystem metabolism in headwater streams of a Kenyan river. Biogeochemistry 132, 1-22 (2017). https://doi.org/10.1007/s10533-016-0269-6

Nienje, A.B., Sivalingam, P., Laffite, A., Ngelinkoto, P., Otamonga, J-P \& Matand, A et al (2017). Microbiological quality of water in a city with persistent and recurrent waterborne diseases under tropical sub-rural conditions: The case of Kikwit City, Democratic Republic of the Congo. International Journal of Hygiene and Environmental Health Volume 220, Issue 5, July 2017, Pages 820-828. https://doi.org/10.1016/j.ijheh.2017.03.011

Osman, A \& Kloas, W (2010). Water Quality and Heavy Metal Monitoring in Water, Sediments, and Tissues of the African Catfish Clarias gariepinus (Burchell, 1822) from the River Nile, Egypt," Journal of Environmental Protection, Vol. 1 No. 4, 2010, pp. 389-400. doi: 10.4236/jep.2010.14045.

Peckham, S \& Awofeso, N (2014). Water fluoridation: a critical review of the physiological effects of ingested fluoride as a public health intervention, Sci. World J. 2014 (2014) 10 Art. no. 293019

WHO (2004). Guidelines for Drinking water Quality. World Health Organization, Geneva, Switzerland, $3^{\text {rd }}$ Edition.

WHO (2017). Guidelines for Drinking water Quality. Fourth Edition incorporating the First Addendum; World Health Organization, Geneva, Switzerland, 2017. 